\title{
ШЕКСПИРОСФЕРА
}

DOI: $10.17805 /$ ggz.2020.6.5

\section{Произведения Шекспира в музыке Йозефа Гайдна}

\author{
T. В. Боровикова \\ Детская школа искусств № 5 , \\ 2. о. Любериы Московской области
}

Статья посвящена произведениям австрийского композитора Йозефа Гайдна (1732-1809) на сюжеть Уильяма Шекспира. К ним относятся эпизодическая музыка к спектаклю «Гамлет», созданная в период работы Гайдна капельмейстером при дворе князя Миклоша Эстерхази, и канцонетта «Cтрасть её таилась молча» ("She Never Told Her Love”), написанная во время вторых гастролей в Англии.

О театре князя Эстерхази известно не много, поэтому в статье сделан обзор деятельности этого театра, в частности постановок под руководством режиссёра Карла Вара, чей коллектив играл спектакли по шести пьесам английского драматурга. Актуальность исследования заключается в том, что вхождение литературного наследия Шекспира в музыкальный репертуар континентальной Европь принято изучать на примере деятельности композиторов XIX в., тогда как созданной в XVIII в. музыке на шекспировские сюжеты достаточного внимания не уделялось.

В статье утверждается, что произведения Гайдна на сюжеты Шекспира появились в период, когда композиторы континентальной Европы только начинали обращаться к сочинениям, связанным с творчеством английского драматурга. Для обоснования этого утверждения в исследовании выявляются музыкальные произведения европейских композиторов XVIII в., вдохновленные писателем. Выявленные примеры позволили установить, что до Гайдна музыкальные сочинения на сюжеты Шекспира были представлены только оперой Франческо Марии Верачини «Розалинда», фантазией на тему «Гамлет» Карла Филиппа Эммануила Баха, оперой Луи-Августа Папавуана «Старый холостяк, или Две подружки» и балетом в постановке Жан-Жоржа Новерра «Антоний и Клеопатра». В период создания произведений Гайдном к литературному наследию Шекспира обращались преимущественно оперные композиторы: Луи-Огюст Папавуан, Йиржи Антонин Бенда, Фердинандо Бертони, Николя Далейрак, Иоганн Генрих Ролле, Гаэтано Андреощии, Даниэль Готлиб Штейбельт, Антонио Сальери.

Автор приходит к выводу о том, что музыкальные произведения Гайдна внесли вклад в распространение шекспировского наследия на раннем этапе 
вхождения английского драматурга в музыкальный культурный канон Европьл и обогащение вокального репертуара Великобритании и США.

Ключевые слова: У. Шекспир; Йозеф Гайдн; Карл Вар; «Гамлет»; «Двенадияатая ночь»; опера XVIII века; дворец Эстерхаза

\title{
Joseph Haydn's Works Inspired by Shakespeare
}

\author{
T. V. Borovikova \\ Children's School of Arts No. 5, \\ Lyubertsy Urban District, Moscow Oblast
}

The article examines the music set to Shakespeare's works by the 18th-century Austrian composer Joseph Haydn. This includes the incidental music to "Hamlet" composed when Haydn was serving as Kapellmeister at the court of Prince Nikolaus Esterházy and the canzonetta "She Never Told Her Love" created during his second journey to London.

As the Esterházy theatre has not been studied in detail, the article includes the outline of the theatre's history and productions directed by Karl Wahr, whose company played in six adaptations based on the English playwright's works. The relevance of the research consists in the fact that the transfer of Shakespeare's literary legacy to the music repertoire in continental Europe has been mostly examined through the works by the 19th-century composers, while the 18th-century music inspired by Shakespeare has been underestimated.

The author argues that Haydn's works based on Shakespeare appeared when the composers of continental Europe had a less developed tradition of setting music to writings related to the English playwright. In order to support the argument, the research identifies the 18th-century pieces of continental music inspired by the writer. These examples have provided evidence that when Haydn turned to Shakespeare's works in the 1770s, the only Shakespearean compositions were the opera "Rosalinda" by Francesco Maria Veracini, the "Hamlet" fantasy" by Carl Philipp Emanuel Bach, the opera "Le Vieux Coquet, ou les deux amies" by Louis-August Papavoine and the ballet "Antoine et Cléopâtre" by Jean-Georges Noverre. In Haydn's time, mostly opera composers were paying attention to Shakespeare's heritage (Louis-August Papavoine, Jiři Antonín Benda, Ferdinando Bertoni, Nicolas Dalayrac, Johann Heinrich Rolle, Gaetano Andreozzi, Daniel Gottlieb Steibelt, Antonio Salieri).

The article makes a conclusion that Haydn's works contributed to spreading Shakespeare's legacy at the early stage of the transcontinental migration of the playwright into the European musical canon as well as to the enrichment of the vocal repertoire in the UK and the USA. 
Keywords: W. Shakespeare; Joseph Haydn; Karl Wahr; "Hamlet”; "Twelfth Night”, 18th-century opera; Esterházy palace

\section{ВВЕДЕНИЕ}

Вхождение сюжетов У. Шекспира, в частности «Цимбелина», «Гамлета», «Ромео и Джульетты», «Сна в летнюю ночь», «Короля Лира», «Макбета», «Отелло», в музыкальный репертуар Европы обычно связывают с XIX в., периодом романтизма: произведениями Франца Шуберта, Феликса Мендельсона, Гектора Берлиоза, Ференца Листа, Рихарда Штрауса, Иоганнеса Брамса, Антонина Дворжака и Петра Чайковского. Тем не менее обращение романтиков к Шекспиру, возможно, не стало бы ярким без музыки композиторов венской классической школы, сочинивших несколько произведений на сюжеты английского драматурга. Среди венских классиков раньше других сюжеты Шекспира появились в творчестве Йозефа Гайдна (1732-1809). К произведениям Гайдна на такие сюжеты относятся музыка к спектаклю «Гамлет» и канцонетта на слова из «Двенадцатой ночи» «Страсть её таилась молча» (“She Never Told Her Love”), сочинение XXVIa № 34.

Актуальность исследования заключается в том, что вхождение литературного наследия Шекспира в музыкальный репертуар больше изучалось на материале творчества композиторов XIX в., тогда как музыке XVIII в., вдохновленной шекспировскими сюжетами, уделялось меньшее внимание. Что касается новизны исследования, необходимо отметить, что, хотя жизнь и творчество Гайдна изучены достаточно, ранний период его работы капельмейстером, особенно связанный с должностью музыкального руководителя театральной труппы Карла Фридриха Вара (ок. 1745-1811), требует большего внимания, что можно отметить и в отношении вклада австрийского композитора в распространение наследия Шекспира. В свою очередь, коллектив Вара активно ставил пьесы Шекспира в 1770-е гг. Важность этого периода состоит в том, что XVIII в. представляет собой время, когда наследие английского драматурга стало восприниматься как особая ценность.

Произведения Гайдна на сюжеты Шекспира появились в период, когда композиторы континентальной Европы только начинали создавать музыку на сюжеты английского драматурга. Для обоснования данного утверждения в исследовании составлен хронологический перечень созданных в XVIII в. в Европе музыкальных произведений на сюжеты Шекспира. Такой перечень позволит проследить распространение шекспировских произведений в музыкальном репертуаре и проанализировать произведения Гайдна в контексте музыки на такие сюжеты у других композиторов. Музыка на сюжеты Шекспира британских композиторов, в частности Генри Пёрселла, Уильяма Шильда, Томаса Арна, в рамки исследования не входит. 
МУЗЫКАЛЬНЫЕ СПЕКТАКЛИ НА СЮЖЕТЫ ШЕКСПИРА В ТЕАТРАХ ХVIII В. И В ТЕАТРЕ КНЯЗЯ МИКЛОША ЭСТЕРХАЗИ

Вторая половина XVIII в., период деятельности Гайдна, стала временем распространения произведений английского драматурга и осознания важности Шекспира для искусства Европы. С 1744 г., времени создания оперы Франческо Марии Верачини «Розалинда», по 1799 г., когда Антонио Сальери написал оперу «Фальстаф, или Три шутки», появилось около 30 музыкальных спектаклей на сюжеты девяти произведений, в основном трагедий. После «Розалинды» по мотивам «Как вам это понравится» во второй половине XVIII в. оперы и балеты на сюжеты Шекспира создавались композиторами Франции, Чехии, Италии и Германии. К таким музыкальным постановкам относятся опера Луи-Августа Папавуана «Старый холостяк, или две подружки» по «Виндзорским насмешницам» 1761 г., балет Жан-Жоржа Новерра «Антоний и Клеопатра» ок. 1761 г., опера Йиржи Антонина Бенды «Ромео и Джульетта» 1776 г., опера Иоганна Готфрида Шваненбергера «Ромео и Джульетта» 1776 г., опера Франца Аспльмайера «Жизнь и смерть короля Макбета» 1777 г., музыка к спектаклю «Гамлет» Георга Йозефа Фоглера 1778 г., опера Иоганна Кристофа Каффки «Антоний и Клеопатра» 1779 г., опера Фердинандо Бертони «Герцог Афинский» 1780 г. по мотивам «Укрощения строптивой», опера Иоганна Генриха Ролле «Буря» 1782 г., балет Эусебио Луцци «Ромео и Джульетта» 1785 г., балет Шарля Ле Пика «Макбет» 1785 г., балет Франческо Клерико «Гамлет» 1788 г., балет Луиджи Марескальки «Ромео и Джульетта» 1789 г., опера Сигизмунда Румлинга «Ромео и Джульетта» 1790 г. (Захарова, Захаров, 2011-: Электронный pecypc; Brissenden, 2001: 34; Griffel, 2018: 425).

Для систематизации перечисленных произведений следует отметить несколько фактов. По «Ромео и Джульетте» во второй половине XVIII в. создали шесть опер и два балета. На сюжеты «Гамлета», «Макбета» и «Ромео и Джульетты» были поставлены и оперы, и балеты. Верачини, Папавуан, Аспльмайер и Каффка впервые создали оперы на сюжеты «Как вам это понравится», «Виндзорских насмешниц», «Антония и Клеопатры» и «Макбета» соответственно. Есть предположение, что Вольфганг Амадей Моцарт в конце жизни намеревался создать оперу по пьесе «Буря» (Eisen, 1991: 66). При этом в его опере «Волшебная флейта» можно найти сходство с этим произведением. Примечателен интерес композиторов того времени к трагедии «Антоний и Клеопатра», которая позднее в музыке была представлена относительно редко. Следует также отметить, что в начале XVIII в. в Италии было поставлено несколько опер «Гамлет», но они, возможно, создавались по либретто, относившимся больше не к произведению Шекспира, а к «Саге о Гамлете» из «Деяний данов» Саксона Грамматика (Cholij, 2001b: 327). 
К началу 1770-х гг., времени, когда Гайдн обратился к сюжету Шекспира, среди музыкальных произведений, связанных с творчеством английского драматурга, можно отметить упоминавшиеся выше оперу Верачини и балет в постановке Новерра, а также фантазию на тему «Гамлет» К. Ф. Э. Баха 1753 г. Таким образом, музыку Гайдна к спектаклю «Гамлет» можно считать одним их первых известных случаев сочинения эпизодической музыки к произведению Шекспира в континентальной Европе. Спектакль «Гамлет» при участии Гайдна в качестве музыкального руководителя был поставлен режиссёром Варом около 1774 г. в театре князя Миклоша Эстерхази (1714-1790) (Sisman, 1990: 325). Обращение к Шекспиру — в определенной степени под влиянием переводов на немецкий язык, выполненных Кристофом Мартином Виландом, - в то время заметно проявилось в формировании предшествовавшего романтизму направления «Буря и натиск», которое развивал в своих симфониях Гайдн. Композитор использовал музыку к спектаклю «Гамлет» в симфонии № 65. Его симфония № 64, названная по-латыни “Тempora mutantur" («Времена меняются»), также могла быть навеяна хрестоматийными словами принца Датского “The time is out of joint” (I, 5).

Нот с музыкой Гайдна к спектаклю «Гамлет» не сохранилось. Князь Эстерхази не разрешал исполнять заказанные им произведения за пределами своих владений. В 1779 г. здание театра сгорело и рукописи могли оказаться утраченными. Так погибли ноты опер Гайдна почти ко всем спектаклям театра марионеток, ставившимся у Эстерхази. Несмотря на отсутствие нот, исследователи и прошлого (Pohl, 1878: 12; Horányi, 1962: 93) и более современного (Sisman, 1990: 325; Cholij, 2001a: 185) периодов, в том числе Х. Ч. Роббинс Лэндон (Robbins Landon, 1978: 216), один из наиболее авторитетных исследователей жизни и творчества Гайдна, упоминали музыку к спектаклю «Гамлет», никогда не отрицая авторства австрийского музыканта. В пользу предположения о создании Гайдном музыки к постановке Вара указывает то, что композитор написал музыкальное сопровождение и к другим спектаклям этого режиссёра, в частности к пьесе «Рассеянный» французского драматурга Жана Франсуа Реньяра. Позже Гайдн создал на основе музыки к тому спектаклю симфонию № 60. Ранее высказывались предположения, что Гайдном также была написана музыка к спектаклю «Король Лир». Немецкий музыковед и композитор Гуго Даффнер даже сообщал о нотах, хранившихся в Дрезденской публичной библиотеке (Daffner, 1914: 52), но позже авторство Гайдна было поставлено под сомнение, в частности музыковедом Иреной Чолидж, считающей, что музыку к «Королю Лиру» сочинили в начале XIX в. (Cholij, 2001a: 185). О нахождении этих нот, как и архивов многих других композиторов, не известно, так как библиотека серьёзно пострадала в конце Второй мировой войны. 
Что касается дворца князя Эстерхази, где Гайдн работал капельмейстером, то он известен как крупнейший в Венгрии архитектурный ансамбль в стиле барокко или венгерский Версаль. Сейчас он включён в Список памятников всемирного культурного наследия ЮНЕСКО. В 1762 г., в эпоху Просвещения, когда сила разума признавалась выше сил природы, князь Эстерхази решил построить резиденцию близ Нойзидлер-Зе, одного из крупнейших в Центральной Европе озёр на границе Австрии и Венгрии. В качестве места для строительства была выбрана заболоченная местность, находившаяся на территории поселения Фертёд. Это название происходит от Фертё - венгерского названия озера. Фертёд расположен в 25 километрах от старинного венгерского города Шопрона.

В 1768 г. при дворце был возведён театр с отапливаемым залом на 400 мест. Инженерные конструкции позволяли создавать световые эффекты и быстро менять декорации. Отдельно выстроили дом для актёров и музыкантов. Театр при дворце можно было считать одним из культурных центров всей Европы, поскольку князь разрешал посещать оперные спектакли, не взимая платы и без сословных ограничений. На открытии театра исполняли оперу Гайдна «Аптекарь» на сюжет одноимённой пьесы Карло Гольдони. Премьеры почти всех опер композитора состоялись в театре этого дворца. С этим дворцом связана история создания Гайдном знаменитой «Прощальной» симфонии № 45, выдержанной в стилистике «Бури и натиска». В 1773 г. во дворце прошли торжества в честь визита императрицы Марии Терезии из династии Габсбургов. Хотя театр Эстерхази был преимущественно музыкальным, известно о драматических постановках. В стихотворении о приемах у князя, созданном венгерским поэтом и драматургом XVIII в. Дьёрдем Бешшеньеи «Празднества в Эстерхазе», упоминаются персонажи спектакля по пьесе французского автора Шарля Колле (Horányi, 1962: 74). Благодаря замечательному дворцу и гостеприимству его хозяина, князя называли Великолепным - с этим прозванием князь Миклош Эстерхази стал известен как один из покровителей искусства в эпоху Просвещения.

Князь, стремившийся следовать новым веяниям в искусстве, заключил договор на постановку спектаклей с малоизвестной труппой Вара, игравшей в том числе пьесы, которые были на тот момент недавно переведены. Примечательно, что семья Эстерхази пригласила Гайдна как одного из музыкальных руководителей, когда композитор только начинал карьеру, таким образом предпочтя более светскую музыку по сравнению с той, которая создавалась Грегором Вернером, предыдущим капельмейстером при дворе Эстерхази. У князя Эстерхази Вар работал режиссером с 1772 по 1777 г. Коллективом под руководством Вара были представлены одни из самых первых постановок 
спектаклей по шести пьесам Шекспира на немецком языке: «Гамлет», «Макбет», «Отелло», «Король Лир», «Ричард ІІІ» и «Ромео и Джульетта». Князь благосклонно относился к коллективу, регулярно выплачивал актёрам жалованье и дополнительные средства. Труппа работала и жила при дворце с апреля по октябрь, а зимой актёры гастролировали. Таким образом у актёров была возможность подготовиться к сезону городских театров. Помимо театра князя, спектакль «Гамлет» труппы Вара с 1773 по 1779 гг. был показан в Пресбурге, Зальцбурге, Пеште и Праге (Sisman, 1990: 325). На гастролях в декабре 1775 г. в Зальцбурге спектакли «Гамлет» и «Ромео и Джульетта» посетил Моцарт, в то время служивший при дворе архиепископа Зальцбурга. В Пресбурге (сейчас - Братислава) актёры играли в театре знатного графа Юрая Чаки де Корёссег и Адорьян IV. В 1776 г. этот граф построил в Пресбурге действующий до сих пор каменный театр, в котором труппа Вара исполняла пьесы Шекспира.

Для спектаклей использовались переводы, выполненные австрийским автором пьес и водевилей Францем фон Хойфельдом, некоторое время руководившим «Кернтнертортеатр» в Вене. Пьесы в тот период адаптировались по принятым канонам: действие разворачивалось в течение одного дня, сюжет упрощался, трагичность сглаживалась. В одной из рецензий постановку хвалили за то, что удалось не допустить смерти восьми персонажей, в отличие от замысла Шекспира. В адаптации «Гамлета» Хойфельда это проявлялось в том, что отсутствовали многие персонажи: Розенкранц, Фортинбрас, Лаэрт, могильщики. Офелия не сходила с ума и не погибала, а ушла в монастырь (Sisman, 1990: 323).

В начале своей карьеры, в середине 1760-х гг., Вар играл в Гамбурге, затем, присоединившись к коллективу комика Иоганна Йозефа Феликса фон Курца, гастролировал в Майнце, Мангейме, Франкфурте-на-Майне и Аугсбурге. В 1771 г. он основал собственную труппу, куда из предыдущего коллектива перешли София и Ян Кёрнеры. Актеры выступали в городах Австрии, а также в Пресбурге, Праге и Пеште (Jakubcová, 2007: Электронный ресурс). В театральном коллективе, игравшем у князя Эстерхази, первоначально было примерно 17 человек из нескольких актерских семей, например супруги София и Ян Кёрнеры, Магдалина и Антонин Заппе, Нанетт и Иоганн Георг Ридли. В 1772 г. коллектив расширился. Актриса Нанетт Ридль выступала в роли Леди Капулетти в «Ромео и Джульетте». Францишка Рейнер играла королеву Елизавету в «Ричарде III». София Кёрнер была первой исполнительницей Дездемоны в «Отелло» в Германии, играла ведущие роли в «Ричарде III» и «Ромео и Джульетте». Кристоф Людвиг Зайп играл Яго в «Отелло». В адаптации того же режиссёра ставился «Король Лир» - спектакль, который хорошо был принят князем Эстерхази, однако автор перевода на немецкий язык К. М. Виланд 
эту постановку подверг критике. Позже к труппе присоединился чешский актёр Франтишек Булла, исполнявший роли сэра Кейтсби в «Ричарде III» и Макбета в одноимённой трагедии. Впоследствии Зайп и Булла продолжали успешно ставить пьесы Шекспира во многих городах Восточной Европы. Ещё одним актёром и помощником Вара был Христиан Генрих Шпис, позднее ставший автором приключенческих романов, популярных в XIX в. у европейских, в частности российских, читателей.

По окончании контракта с Эстерхази в 1777 г., когда была приглашена труппа Эрнста Паули и Майера, сохранивших в репертуаре пьесы Шекспира, Вар руководил театром в Пресбурге. В 1783 г. он переехал в Прагу, где работал режиссером только что открывшегося театра графа Ностица - театра, известного сейчас как Сословный театр, в котором Вар поставил «Макбета» и оперу Моцарта «Похищение из сераля». Последней режиссёрской работой Вара стала драма Августа фон Коцебу «Ненависть к людям и раскаяние», показанная осенью 1811 г. в Риге. В этом городе Вар скончался.

Вар-актёр был известен исполнением роли Гамлета. В целом он пользовался популярностью у зрителей, хотя его иногда считали не совсем профессиональным актёром. По воспоминаниям и рецензиям стиль его игры имел черты сходные с исполнением Дэвида Гаррика (Sisman, 1990: 320). Как режиссер Вар подчёркивал важность музыкальной составляющей драматических спектаклей. Не исключено, что благодаря именно его постановкам, которые сохраняли первоначальную интерпретацию произведений и в подготовке которых принимал участие Гайдн, публика немецкоязычных стран стала больше интересоваться произведениями Шекспира - ведь до того момента драматург оставался лишь одним из множества авторов, а не классиком.

\section{ПРОИЗВЕДЕНИЯ ШЕКСПИРА В МУЗЫКЕ 1790-Х ГГ. И АНГЛИЙСКАЯ КАНЦОНЕТТА ГАЙДНА "SHE NEVER TOLD HER LOVE"}

В 1790-х гг. сюжеты Шекспира в музыке были представлены операми Николя Далейрака «Всё ради любви, или Ромео и Джульетта» 1792 г., Гаэтано Андреоцци «Гамлет» 1792 г., Даниэля Штейбельта «Ромео и Джульетта» 1793 г., Петера Риттера «Виндзорские насмешницы» 1794 г., Никколо Антонио Дзингарелли «Джульетта и Ромео» 1796 г., Карла Диттерса фон Диттерсдорфа «Виндзорские насмешницы», Антонио Сальери «Фальстаф, или Три шутки» 1799 г. (Захарова, Захаров, 2011-: Электронный ресурс; Griffel, 2018: 425). С 1795 г. по 1800 г. было создано пять опер на сюжет «Бури».

Й. Гайдн после музыки к спектаклю «Гамлет» в 1770-е гг. вернулся к шекспировскому творчеству через 20 лет, во время вторых гастролей в Англии 1794-1795 гг., но он обратился не к сформировавшейся на тот момент форме крупных произведений, а к песенному жанру, представленному в том числе 
канцонеттами. О том периоде жизни и творчества композитора следует отметить, что 13 октября 1794 г. Гайдн присутствовал в «Ковент-Гардене» на спектакле «Гамлет», исполнявшегося с музыкой У. Шильда. Из Англии композитор привёз собрание пьес Шекспира в десяти томах под редакцией Сэмюэля Джонсона и Джорджа Стивенса, издание 1785 г. (MacIntyre, 1998: 10). Гайдн, вероятно, замечал сходство своей музыки с творчеством драматурга. Музыковед Чарльз Бёрни упоминал Шекспира в приветственном стихотворении по случаю первых гастролей Гайдна в Англии в 1791 г. (Peter Brown, 2002: 95). По свидетельству французского флейтиста Луи Друэ, композитор говорил о творчестве Шекспира и в беседе с Бетховеном: «Взгляни на мои сочинения. В них всегда можно найти что-то задорное, потому что я сам такой; ведь рядом с серьезным всегда можно найти веселое, как в трагедиях Шекспира» (цит. по: Sisman, 1997: 24; здесь и далее перевод наш. - Т. Б.). С Бетховеном Гайдн встречался в Бонне в 1792 г. по возвращении из Лондона, т. е. тогда Гайдн знал произведения драматурга. В первой четверти XIX в. Бетховен, ученик Гайдна, также представитель венских классиков, начинал сочинение оперы «Макбет», которая осталась неоконченной.

В Лондоне среди знакомых Гайдну людей была Энн Хантер, супруга известного британского врача Джона Хантера. Она была поэтессой, некоторые стихи которой композитор выбрал для сочинения «Английских канцонетт» со словами на английском языке. Также она могла предложить стихотворения других поэтов для этих канцонетт. В Англии канцонетты представляли собой малые вокальные лирические произведения. Сборник Гайдна в двух частях состоял из 12 канцонетт, стилизованных под английские песенные жанры, такие как матросская песня, пасторальная песня, плач, готическая песня, лирическая песня. Ранее композитор сочинял малые вокальные произведения. К тому времени у него уже был опубликован сборник немецких песен, но в Англии ему нужно было создать музыку на основе английской песенной традиции и на английском языке, хотя Гайдн по-английски говорил с трудом. В первую часть сборника была включена канцонетта «Песнь духа» (“The Spirit's Song”) на слова Э. Хантер, но Гайдн полагал, что создавал канцонетту на слова Шекспира. Во второй части, вышедшей в 1795 г. в лондонском издательстве знакомых Гайдну композиторов Доменико Корри и Яна Дусека (Haydn, s.d.; Grigson, 2009: 85), содержались канцонетты на слова нескольких авторов. Эту часть сборника Гайдн посвятил Шарлотте Берти, супруге композитора Уиллоуби Берти Абингдона, помогавшего Гайдну с организацией концертов в Лондоне. Возможно, это посвящение было связано с тем, что в 1794 г., когда сборник создавался, Берти скончалась.

Во вторую часть сборника входила и канцонетта, созданная как элегия, «Страсть её таилась молча» с монологом Виолы из «Двенадцатой ночи». Не 
исключено, что эта пьеса была известна композитору. В лондонских газетах описание гастролей сопровождались цитатами из этой комедии, прежде всего «О, музыка, ты пища для любви!» (Robbins Landon, 1976: 41). Важный факт, касающийся истории создания этой канцонетты, представляет собой более раннее обращение к монологу Виолы в английской музыке. В начале 1790-х гг. английский врач и композитор-любитель Генри Харингтон из курортного города Бата, основатель городского музыкального общества, а впоследствии мэр города, сочинил в 1790 г. терцет «Рассказ Виолы о своей тайной любви» ("Viola's Account of Her Own Conceal'd Love") на тот же отрывок из пьесы (Harington, 1800: 8-10). Гайдн, вполне возможно, знал об этом терцете, поскольку поддерживал дружеские связи с Харингтоном. Он, став к тому времени почётным доктором музыки Оксфордского университета, приезжал к этому английскому музыканту в Бат в 1794 г. и сочинил на слова английского коллеги вокальное произведение «Комплимент доктора Харингтона» (“Dr. Harington's Compliment").

Интересно, что, хотя в «Двенадцатой ночи» упоминаются несколько песен, например, «Эй, Робин, милый Робин» (“Hey, Robin, Jolly Robin”) (IV, 2), «Когда я ростом да был еще с вершок» (“When that I was and a little tiny boy”) $(\mathrm{V}, 1)$, Гайдн обратился к сцене, не предполагавшей музыкального сопровождения. Слова канцонетты представляют собой отрывок из «Двенадцатой ночи» (II, 4), в котором Виола, переодетая в Цезарио, рассказывает герцогу Орсино о несчастной любви якобы скончавшейся сестры, при этом выражая собственные чувства:

A blank, my lord. She never told her love,

But let concealment, like a worm i' th' bud,

Feed on her damask cheek. She pined in thought,

And with a green and yellow melancholy

She sat like patience on a monument,

Smiling at grief. Was not this love indeed?

We men say more, swear more, but indeed

Our shows are more than will; for still we prove

Much in our vows, but little in our love.

(II, 4; Shakespeare, 1998: 140)

Перевод М. Л. Лозинского:

В ней белые страницы. Страсть её

Таилась молча и, как червь в цветке,

Снедала жар ее ланит; в зеленой 
И желтой меланхолии она

Застыла, как надгробная Покорность, И улыбалась. Это ль не любовь?

Мы больше говорим, клянемся больше;

Но это - показная сторона:

Обеты щедры, а любовь бедна.

(Шекспир, 1937: 409)

В качестве названия произведения Гайдн выбрал слова "She never told her love", тем самым сделав их отдельной распространенной цитатой Шекспира. Композитор сократил первоначальный текст, что может быть связано с тем, что за основу был взят не полный монолог Виолы, а фрагмент, который неоднократно со второй половины XVIII в. публиковался отдельно в сборниках произведений английских поэтов. В одном из первых таких изданий, выпущенном в 1777 г., отрывок со словами Виолы назывался «Тайная любовь» (“Concealed Love") (The poetical preceptor ..., 1777: 248). Он гораздо больше сопоставим по объёму словам канцонетты Гайдна. Следовательно, композитор создавал музыку не к полному монологу Виолы, а к адаптированному тексту, известному как стихотворение «Тайная любовь»:

She never told her love,

But let concealment, like a worm i' th' bud,

Feed on her damask cheek; she pin'd in thought;

And, with a green and yellow melancholy,

She sat like patience on a monument,

Smiling at grief.

(ibid.: 248)

По сравнению со стихотворением из издания 1777 г. в канцонетте Гайдна пропущено "she pin'd in thought; and, with a green and yellow melancholy", но повторяются слова первой строки "She never told her love" и конечная строка "Smiling at grief". Заключительная часть организована в форме приёма, основанного на повторении, — анадиплосиса: "She sat like Patience on a Monument, smiling, / Smiling at grief, smiling at grief". Вносил ли композитор лично изменения в структуру текста канцонетты, не известно. Канцонетта Гайдна содержит слова Виолы в таком варианте:

She never told her love,

She never told her love,

But let concealment, like a worm in the bud, 
Feed on her damask cheek

She sat like Patience on a Monument, smiling,

Smiling at grief, smiling at grief.

(Haydn, s.d.: 14-15)

Несомненно, композитор с особым старанием отнесся к созданию произведения на слова Шекспира. Эту канцонетту можно считать миниатюрой с вокальным аккомпанементом, что представляет собой оригинальное и редкое воплощение музыкального замысла. Из 39 тактов фортепиано только 19 предназначались для вокальной партии. Характер исполнения этой музыкальной миниатюры обозначается в партитуре Largo assai e con espressione (очень протяжно и выразительно). Она написана в сквозной форме, форме вокальной музыки, характеризующейся разнообразием мелодии. Такая форма стала в дальнейшем распространенной у композиторов-романтиков: в песнях Франца Шуберта, а позже в операх Рихарда Вагнера. В некоторой степени эта канцонетта обладает сходством с песней (Lied) и романсом. Таким образом, с этой канцонетты начинается этап музыки на сюжеты Шекспира периода романтизма. Песенную традицию на шекспировские сюжеты продолжили жившие в Вене композиторы: Шуберт, сочинивший «Песню (к Сильвии)» и «Серенаду» на стихи из «Двух Веронцев» и «Цимбелина» соответственно, а также Брамс, создавший, будучи руководителем Венской филармонии, пять «Песен Офелии».

В отличие от музыки к «Гамлету», канцонетта сохранились. После первой публикации 1795 г. в Лондоне (Haydn, s.d: 14-15; Grigson, 2009: 85), она переиздавалась (Haydn, 1800: 1), а Лейпцигское издательство «Брайткопф и Гертель» подготовило сборник, включавший эту канцонетту с переводом на немецкий язык:

Stets barg di Liebe sie,

Stets barg di Liebe sie,

doch dieses Bergen,

wie in Knospen ein Wurm,

zehrt' ihre Wange ab.

Sie glich der Duldung auf dem Grabmal, lächelnd,

lächelnd traur'gen Blicks,

lächelnd traur'gen Blicks.

(Haydn, 1803: 76-77)

О распространенности канцонетты Гайдна и ее известности в искусстве романтизма свидетельствует то, что название "She Never Told Her Love" 
можно встретить у английского композитора Клары Кэтлин Роджерс, сочинившей в 1892 г. музыку на слова, точно повторяющие вариант для канцонетты Гайдна, и английского художника и фотографа Генри Пича Робинсона, создавшего в 1857 г. одноимённую фотографию. Одной из самых известных исполнительниц канцонетты Гайдна в XIX в. была оперная певица российского происхождения Гермина Рудерсдорф (1822-1882). Она, выросшая в семье скрипача Иосифа Рудерсдорфа, прославилась в Европе как педагог по вокалу. Г. Руденсдорф выступала с этой канцонеттой на концертах Гюрценихоркестра в Кельне и в зале «Гевандхауз» в Лейпциге (Gänzl, 2018: 597). B peцензиях отмечалось её исполнение канцонетты «с восхитительной сладостью», «с изяществом, простотой и чувством» (ibid.: 92).

Канцонетта до сих пор включается в вокальный репертуар (Manning, 2020: 329). В XX-XXI вв. она исполнялась в Германии, Великобритании, Швеции, Нидерландах и США певицами Ирмгард Зефрид, Элли Амелинг, Арлин Ожер, Анне Софи фон Оттер. Хотя канцонетта написана для голоса меццосопрано, исполнение мужским голосом оправдано тем, что в пьесе Виола говорит от лица пажа Цезарио. Среди мужчин, исполнявших произведение, певцы Дитрих Фишер-Дискау, Лоренс Дейл, Марк Падмор, Кристоф Генц. Традиция аудиозаписи этой канцонетты весьма богата. В первой половине XX в. её записали на пластинки американские исполнители Мариан Андерсон, Элизабет Шуман, Лора Литтлфилд, Эдди Кантор (<Результаты по поисковому запросу "she never told her love">, б/д: Электронный ресурс). В России канцонетта на слова Шекспира известна мало и в концертный репертуар не входит. Например, в 1983 г. на фирме «Мелодия» была выпущена грампластинка с записью всех «Английских канцонетт» в исполнении певицы Галины Писаренко, кроме «Страсть её таилась молча» (Гайдн, 1983).

О вокальных сочинениях малой формы на мотивы Шекспира в континентальной Европе, созданных до Гайдна, какие-либо сведения отсутствуют, в связи с чем этого композитора важно выделить как одного из ранних авторов произведений малой формы на сюжеты Шекспира с элементами, характерными для романтизма - последующего этапа развития классической музыки. Популярность канцонетты «Страсть её таилась молча» в англоязычных странах свидетельствует о том, что произведение композитора венской классической школы на слова из пьесы Шекспира получило признание на родине драматурга.

\section{ЗАКЛЮЧЕНИЕ}

Й. Гайдна по праву считают новатором в музыке XVIII в. Среди композиторов венской классической школы он стал первым, кто начал сочинять му- 
зыкальные произведения, основанные на сюжетах Шекспира. Этот композитор как музыкальный руководитель труппы К. Ф. Вара и капельмейстер князей Эстерхази участвовал в подготовке ранних постановок пьес английского драматурга в немецкоязычных странах. В период гастролей в Англии он создал одно из первых музыкальных произведений, связанное с сюжетом пьесы «Двенадцатая ночь». Можно считать, что канцонетта со словами из этой пьесы стала ранним образцом музыки по мотивам пьес Шекспира, сочинённой как произведение периода романтизма. В целом исследование показало, что обращение Гайдна к наследию английского драматурга ознаменовало один из этапов вхождения произведений Шекспира в музыкальный культурный канон Европы и получило признание в англоговорящих странах.

\section{СПИСОК ЛИТЕРАТУРЫ}

Гайдн, Й. (1983) Английские канцонетты : звукозапись : [для сопрано и инструментального ансамбля] / комп. Й. Гайдн ; инструм. Г. С. Зингер ; исполн. Г. А. Писаренко, сопрано, инструментальный ансамбль ; дир. Ю. Николаевский ; звукорежиссер М. Кожухова ; ред. И. Орлова. М. : Мелодия.

Захарова, О. А., Захаров, Н. В. (2011-) Шекспир в европейской музыке [Электронный ресурс] // Электронная энциклопедия «Мир Шекспира». URL: http://world-shake.ru/ru/Encyclopaedia/4021.html [архивировано в Wayback Machine] (дата обращения: 15.11.2020).

$<$ Результаты по поисковому запросу "she never told her love"> (б/д) [Электронный ресурс] // Internet Archive. URL: https://archive.org/search.php? query $=$ she + never+told + her+love (дата обращения: 27.11.2020).

Шекспир, В. (1937) Двенадцатая ночь, или что угодно / пер. М. Л. Лозинского // Шекспир В. Полн. собр. соч. : в 8 т. / под ред. С. С. Диманова, А. А. Смирнова. М. ; Л. : Academia. T. 1. VIII, 771 с. С. 361-480.

Brissenden, A. (2001) Ballet // The Oxford companion to Shakespeare / general editor M. Dobson ; associate general editor S. Wells. Oxford : Oxford University Press. xxix, 541 p. P. 34-35.

Cholij, I. (2001a) Haydn, Franz Josef // The Oxford companion to Shakespeare / general editor M. Dobson ; associate general editor S. Wells. Oxford: Oxford University Press. xxix, 541 p. P. 185.

Cholij, I. (2001b) Opera // The Oxford companion to Shakespeare / general editor M. Dobson ; associate general editor S. Wells. Oxford: Oxford University Press. xxix, 541 p. P. 325-328.

Daffner, H. (1914) Haydn und Shakespeare // Jahrbuch der Deutschen Shakespeare-Gesellschaft. Bd. 50 / hrsg. von A. Brandl, M. Förster. Berlin : Verlag von Georg Reimer. 298 S. S. 51-59. 
Eisen, C. (1991) New Mozart documents: A supplement to O. E. Deutsch's documentary biography. Stanford : Stanford University Press. xvii, $192 \mathrm{p}$.

Gänzl, K. (2018) Victorian vocalists. L. ; N. Y. : Routledge. xvi, 746 p.

Griffel, M. R. (2018) Operas in German: A dictionary : [in 2 vols.] Revised edn. Lanham; Boulder; N. Y. ; L. : Rowman and Littlefield. xxvi, 1017 p.

Grigson, C. (2009) The life and poems of Anne Hunter: Haydn's tuneful voice. Liverpool : Liverpool University Press. xvii, 286 p.

Harington, H. (1800) Songs, duetts, and other compositions. L. : Printed for the author. [iii], 2-65, [1] p.

Haydn, J. (1800) Six original canzonettas for the voice with an accompaniment for the piano-forte. Dublin : Hime's Musical Circulating Library. $11 \mathrm{p}$.

Haydn, J. (1803) Gesaenge mit Begleitung des Piano-Forte. Leipzig: Breitkopf \& Härtel. $100 \mathrm{~S}$.

Haydn, J. (s.d.) Second sett of Dr. Haydn's VI original canzonettas, for the voice with accompaniment for the piano forte. Dedicated to the Right Honble. Lady Charlotte Bertie. L. ; Edinburgh : Corri Dussek \& Co. [2], 23, [1] p.

Horányi, M. (1962) The magnificence of Eszterháza. Budapest : Akadémiai Kiadó. 260 p.

Jakubcová, A. (2007) Wahr, Karl // Česká divadelní encyklopedie. URL: http://encyklopedie.idu.cz/index.php/Wahr, Karl [архивировано в Wayback Machine] (дата обращения: 15.11.2020).

MacIntyre, B. C. (1998) Haydn: The creation. N. Y. : Schirmer Books ; L. : Prentice Hall International. xviii, $344 \mathrm{p}$.

Manning, J. (2020) Vocal repertoire for the twenty-first century: in 2 vols. N. Y. : Oxford University Press. Vol. 1: Works written before 2000. xv, 351 p.

Peter Brown, A. (2002) Notes on Joseph Haydn's lieder and canzonettas // For the love of music: Festschrift in honor of Theodore Front on his 90th birthday / ed. by. D. F. Scott. Lucca : LIM Antiqua. 307 p. P. 77-104.

Pohl, C. F. (1878) Joseph Haydn. Bd. 1. Leipzig : Breitkopf \& Härtel. xx, 422 S.

Robbins Landon, H. C. (1976) Haydn: Chronicle and works : in 5 vols. Bloomington : Indiana University Press. Vol. 3 : Haydn in England, 1791-1795. 640 p.

Robbins Landon, H. C. (1978) Haydn: Chronicle and works : in 5 vols. Bloomington : Indiana University Press. Vol. 2 : Haydn at Eszterháza, 1766-1790. 799 p.

Shakespeare, W. (1998) Twelfth night, Or what you will / ed. by R. Warren, S. Wells. Oxford : Oxford University Press. viii, 247 p.

Sisman, E. R. (1990) Haydn's theater symphonies // Journal of the American Musicological Society. Vol. 43. No. 2. P. 292-352. DOI: $\underline{10.2307 / 831616}$ 
Sisman, E. R. (1997) Haydn, Shakespeare and the rules of originality // Haydn and his world / ed. by E. R. Sisman. Princeton, NJ : Princeton University Press. xiii, 474 p. P. $3-56$.

The poetical preceptor; or, A collection of select pieces of poetry; extracted from the works of the most eminent English poets, etc. (1777) / [ed. by S. Crowder]. London : Printed for S. Crowder. xvi, 344 p.

Дата поступления: 20.11.2020 2.

\section{REFERENCES}

Haydn, J. (1983) Angliiskie kantsonetty [English canzonettas] : A record : [for soprano and instrumental ensemble] / comp. by J. Haydn; instrumentation by G. S. Singer; performer G. A. Pisarenko, soprano, instrumental ensemble; dir. Yu. Nikolaevsky ; sound engineer M. Kozhukhova ; editor I. Orlova. Moscow: Melodiya Firm.

Zakharova, O. A. and Zakharov, N. V. (2011-) Shekspir v evropeiskoi muzyke [Shakespeare in European music]. Elektronnaia entsiklopediia «Mir Shekspira» [Electronic encyclopedia "The World of Shakespeare"]. [online] Available at: http://world-shake.ru/ru/Encyclopaedia/4021.html [archived in Wayback Machine] (accessed 15.11.2020). (In Russ.).

$<$ Rezul'taty po poiskovomu zaprosu "she never told her love" $>[<$ Results for search query "she never told her love" $>$ ] (s.d.) Internet Archive [online] Available at: https://archive.org/search.php?query=she+never+told+her+love (accessed 27. 11.2020).

Shakespeare, W. (1937) Dvenadtsataia noch', ili chto ugodno [Twelfth night, or What you will] / transl. by M. L. Lozinsky. In: Shakespeare, W. Polnoe sobranie sochinenii [Complete works] : in 8 vols. / ed. by S. S. Dinamov and A. A. Smirnov. Moscow ; Leningrad : Academia Publ. Vol. 1. VIII, 771 p. Pp. 361-480. (In Russ.).

Brissenden, A. (2001) Ballet. In: The Oxford companion to Shakespeare / general editor M. Dobson ; associate general editor S. Wells. Oxford : Oxford University Press. xxix, 541 p. Pp. 34-35.

Cholij, I. (2001a) Haydn, Franz Josef. In: The Oxford companion to Shakespeare / general editor M. Dobson ; associate general editor S. Wells. Oxford: Oxford University Press. xxix, 541 p. P. 185.

Cholij, I. (2001b) Opera. In: The Oxford companion to Shakespeare / general editor M. Dobson ; associate general editor S. Wells. Oxford: Oxford University Press. xxix, 541 p. Pp. 325-328.

Daffner, H. (1914) Haydn und Shakespeare. In: Jahrbuch der Deutschen Shakespeare-Gesellschaft. Bd. 50 / hrsg. von A. Brandl und M. Förster. Berlin : Verlag von Georg Reimer. 298 S. S. 51-59. (In Germ.). 
Eisen, C. (1991) New Mozart documents: A supplement to O. E. Deutsch's documentary biography. Stanford: Stanford University Press. xvii, $192 \mathrm{p}$.

Gänzl, K. (2018) Victorian vocalists. London; New York : Routledge. xvi, $746 \mathrm{p}$.

Griffel, M. R. (2018) Operas in German: A dictionary : [in 2 vols.] Revised edn. Lanham ; Boulder ; New York ; London : Rowman and Littlefield. xxvi, 1017 p.

Grigson, C. (2009) The life and poems of Anne Hunter: Haydn's tuneful voice. Liverpool : Liverpool University Press. xvii, 286 p.

Harington, H. (1800) Songs, duetts, and other compositions. London : Printed for the author. [iii], 2-65, [1] p.

Haydn, J. (1800) Six original canzonettas for the voice with an accompaniment for the piano-forte. Dublin : Hime's Musical Circulating Library. 11 p.

Haydn, J. (1803) Gesaenge mit Begleitung des Piano-Forte. Leipzig: Breitkopf \& Härtel. 100 S. (In Germ.).

Haydn, J. (s.d.) Second sett of Dr. Haydn's VI original canzonettas, for the voice with accompaniment for the piano forte. Dedicated to the Right Honble. Lady Charlotte Bertie. London ; Edinburgh : Corri Dussek \& Co. [2], 23, [1] p.

Horányi, M. (1962) The magnificence of Eszterháza. Budapest : Akadémiai Kiadó. 260 p.

Jakubcová, A. (2007) Wahr, Karl. In: Česká divadelní encyklopedie [online] Available at: http://encyklopedie.idu.cz/index.php/Wahr,_Karl [archived in Wayback Machine] (accessed 15.11.2020). (In Czech).

MacIntyre, B. C. (1998) Haydn: The creation. New York : Schirmer Books ; London : Prentice Hall International. xviii, 344 p.

Manning, J.(2020) Vocal repertoire for the twenty-first century: in 2 vols. New York : Oxford University Press. Vol. 1: Works written before 2000. xv, 351 p.

Peter Brown, A. (2002) Notes on Joseph Haydn's lieder and canzonettas. In: For the love of music: Festschrift in honor of Theodore Front on his 90th birthday / ed. by. D. F. Scott. Lucca : LIM Antiqua. 307 p. Pp. 77-104.

Pohl, C. F. (1878) Joseph Haydn. Bd. 1. Leipzig : Breitkopf \& Härtel. xx, 422 S. (In Germ.).

Robbins Landon, H. C. (1976) Haydn: Chronicle and works: in 5 vols. Bloomington : Indiana University Press. Vol. 3: Haydn in England, 1791-1795. 640 p.

Robbins Landon, H. C. (1978) Haydn: chronicle and works: in 5 vols. Bloomington: Indiana University Press. Vol. 2: Haydn at Eszterháza, 1766-1790. 799 p.

Shakespeare, W. (1998) Twelfth night, or what you will / ed. by R. Warren and S. Wells. Oxford : Oxford University Press. viii, 247 p. 
Sisman, E. R. (1990) Haydn's theater symphonies. Journal of the American Musicological Society, vol. 43, no. 2, pp. 292-352. DOI: $10.2307 / 831616$

Sisman, E. R. (1997) Haydn, Shakespeare and the rules of originality. In: Haydn and his world / ed. by E. R. Sisman. Princeton, NJ : Princeton University Press. xiii, 474 p. Pp. 3-56.

The poetical preceptor; or, A collection of select pieces of poetry; extracted from the works of the most eminent English poets, etc. (1777) / [ed. by S. Crowder]. London : Printed for S. Crowder. xvi, $344 \mathrm{p}$.

Submission date: 20.11.2020.

Боровикова Татьяна Васильевна - преподаватель теоретических дисциплин Детской школы искусств № 5 муниципального образования городской округ Люберцы Московской области, заслуженный работник культуры Московской области. Адрес: 140072, Московская область, городской округ Люберцы, п. Томилино, ул. Тургенева, д. 1. Тел.: +7 (495) 557-51-75. Эл. адрес: albion0@yandex.ru

SPIN-код: $\underline{4833-3000}$

BOROVIKOVA Tatiana Vasilievna, Teacher of Theoretical Disciplines, Children's School of Arts No. 5, Lyubertsy Urban District, Moscow Oblast, Honoured Cultural Worker of Moscow Oblast. Postal address: 1 Turgeneva St., 140072 Tomilino, Lyubertsy Urban District, Russian Federation. Tel.: +7 (495) 557-51-75. E-mail: albion0@yandex.ru

SPIN-code: $\underline{4833-3000}$

Для цитирования:

Боровикова T. В. Произведения Шекспира в музыке Йозефа Гайдна [Электронный ресурс] // Горизонты гуманитарного знания. 2020. № 6. С. 5976. URL: https://journals.mosgu.ru/ggz/article/view/1361 (дата обращения: дд.мм. гггг). DOI: $\underline{10.17805 / \mathrm{ggz} .2020 .6 .5}$ 